\title{
Taking back the power: The link between poverty and Canada's sex industry
}

\author{
Sandra Hodzic, ${ }^{*}$ Robert Chrismas ${ }^{\dagger}$
}

Despite the investment in sophisticated and well-funded counter-exploitation strategies in Canada, women and children continue to be trafficked and sexually exploited each day. Research has provided significant findings, demonstrating close correlations between poverty, homelessness, and deprivation of opportunities for education and employment, and lacking resilience to being targeted and oppressed in the sex industry (Chrismas, 2017).

Cullen-DuPont (2009) has described how traffickers identify people who are desperate to escape poverty by luring them with lies, such as the promise of legitimate work. In some cases, parents sell their children in hopes of a better life. Tragically, however, the hope of legitimate work often turns into torture and servitude to the sex industry.

Chrismas (2017) has characterized the sex industry in Canada as amounting to $21^{\text {st }}$ century slavery, in which children and young women are, at first, lured and then captured in a fully entrenched culture of torture. Human trafficking is the recruitment, transportation, transfer, harbouring or purchase of persons for the sole purpose of exploitation (Glowbal Act, 2018). It happens to men and women, but the base majority of exploited people in Manitoba are women, often introduced to the sex trade industry at an early age. This paper provides context around the impacts that poverty and homelessness have on those who are trafficked, along with recommendations for those looking to get out.

\section{CONTEXT}

Human trafficking involves the illegal transport of people from one place to another to advance forced labour for sexual or commercial gain. The United Nations Office on Drugs and Crime (UNODC) Global Report on Trafficking in Persons 2014 states that human trafficking is universally on the rise (UNODC, 2014; see also Nelson, 2014; Canadian Women's Foundation [CWF], 2014). In Manitoba, there is a growing sense of urgency and need for strategies to combat sexual exploitation and trafficking. Issues around missing and murdered Indigenous women and children (Welch, 2014) continue to shape the public narrative, and government and non-government agencies are increasingly pressed to find more effective ways to respond. These issues have been a rising priority for most police agencies across Canada, as-well-as for leaders in the broad spectrum of partnering agencies (Friesen, 2014; CBC, 2014). Tina Fontaine's murder, among others, has served as a tragic reminder that there is much work to be done to prevent the oppression of vulnerable citizens (Paperney, 2009).

Most sex industry survivors are oppressed, not only from the trauma of being exploited, abused, beaten, and neglected, but also most often from being lost in a sea of fragmented social services and programs that are difficult to navigate. Some elements of our system work well together, while others work in isolation, and some work against each other due to opposing philosophies and competition over limited resources (Chrismas, 2017). Now, more than ever, provincial governments are facing persisting challenges to do more with less money, and fewer resources, due to shrinking federal transfers and a changing demographic, which has placed pressure on the social services sector. Resources that are available are scarce, and social service agencies often struggle to become noticed and ensure their programming is seen as a central priority in order to continue receiving funding supports. This often means that prevention programs are not funded, or not at the same rate as other programs, due to competing demands and political priorities. While most governments strive to strengthen our social safety net, the finite and scarce nature of public resources tackles some problems, but not all. This means that governments, alone, cannot resolve all social ills. Strengthening our social fabric is everyone's responsibility, and individuals in the private and not-for-profit sectors need to be a part of the solution to this set of interconnected social issues that drive marginalized people to a path of destruction. Conventional wisdom in public service is that no one agency can move the needle on most social problems; rather, multiple systems must be coordinated in order to make headway on almost any significant social problem, including human trafficking.

The maze that drives and holds many vulnerable individuals in the sex industry includes unlimited combinations of factors including family dysfunction, educational difficulties, poverty, chemical and substance abuse, involvement with child protective services, friends or family who are involved in trading sex, running away from home, homelessness, school delinquency, and sexual activity. Among these, research suggests that homelessness is an influential factor in individuals entering the sex industry, and it is a fundamental challenge that impoverished people face. 
Raising healthy families is a pre-cursor to stable employment and a necessity for good mental health, something that victims in the sex trade lack. There is overwhelming evidence of the positive correlation between stable housing and home ownership and overall improved quality of life (Partnership for Strong Communities, 2018). Stable home environments, including home ownership, lead to increased community involvement and more economic participation, which gentrifies neighbourhoods, attracts skilled labour, and improves overall job creation (Nelles, 2016). This leads to higher post-secondary graduation rates, better health, increased future earnings' potential, and a better life, which also allows people to be more resilient and less vulnerable to sexual exploitation.

Homeless individuals often come from low-income backgrounds and lack social capital, which Burton refers to in his study of financial and material needs (Burton, 1997). Statistics Canada reported in 2015 that one in five children in Canada's major cities lived in low-income households in 2015 (Press, 2017). Generally speaking, the incidence of low income has been increasing for most subpopulations in Manitoba, as well as at the national level. The percentage of Manitobans living in poverty increased by 21 per cent from 2008 to 2015 compared to an increase of eight per cent for Canada as a whole. Among Indigenous peoples living off-reserve more specifically, poverty rates increased by 54 per cent between 2008 and 2015 (Government of Manitoba, 2018b).

Homelessness drives many people into survival sex, especially in places with harsh winter climates that are so cold one could easily die or lose limbs if safe refuge is denied. Chrismas (2017) documented strong evidence that traffickers specifically target those who are vulnerable due to homelessness and impoverishment, by offering them a means to survive and have a roof over their heads. Affordable housing is a crucial factor in assessing poverty and measuring vulnerability. Some individuals' challenges have been mitigated through government support programs, such as Manitoba Government subsidies that provide over 35,000 affordable housing units to people in need (Government of Manitoba, 2018b). Many of these individuals are unable to access government supports when they need them, because they are either unaware of available programs, or they are busy just trying to stay alive.

While we all know of individuals from disadvantaged environments who later became successful, the fate for most people is to live and die as members of the same socioeconomic classes into which they were born. MacLeod (1995) found that "social reproduction processes" tend to keep people locked in their place in the social-economic order. Following residents of one urban neighbourhood longitudinally, over several decades from childhood on, Macleod found that social structures create a destiny that is difficult to escape. The same dynamics seem to be at play with respect to sex industry survivors. Impoverishment and the related lack of opportunities are clearly linked to people resorting to survival sex. In Canada, and in particular in the Prairies, having a warm refuge from dangerously cold climates is a condition of survival and many resort to trading sex for shelter during the cold winter months. Housing in this context becomes not just a matter of stability, but an urgent matter of life and death.
Previous research has revealed that women who are sexually exploited tend to experience alarming levels of direct physical violence and abuse. Farley (2003), for example, found that most women and youth who are sexually exploited are trapped in violent exploitative relationships where they live in fear, which eventually takes a toll on their mental and physical well-being. A study of 854 survivors in nine countries revealed that violence is the common experience for people in the sex industry (Farley, 2003). Women and youth reported being routinely subjected to various forms of oppression and violence including sexual harassment, verbal abuse, stalking, rape, battering, and torture (Farley, 2003). The lack of housing exacerbates these problems should they try to escape. Chrismas found that even when housing exists, lack of security is a layered problem for survivors as traffickers are relentless in harassing them; housing that is safe and secure is an additional problem for them.

There is a growing awareness of the oppression that Indigenous women and children have suffered historically, and continue to endure in the present day. A substantial body of research has confirmed that Indigenous communities in Canada are still suffering the impacts of colonization (Ham, 2014; Younging, 2009). First Nations women and girls are four times more likely than mainstream Canadians to live in crowded conditions and/or in homes that are in states of ill repair (Mandel, 2016). The continuing marginalization of Indigenous people has also been long-established in the literature that documents higher crime rates, lower employment rates, and overall poor educational outcomes in relation to other Canadians (Hallett, Thornton \& Stewart, 2006).

Indigenous people are migrating in increasing numbers from impoverished reserves into poor neighbourhoods in Canada's urban centers (Norris, Beavon, Guimond et al., 2000; Norris, Kerr \& Nault, 1995). Street gangs often provide the identity and structure that children need and are not finding at home (Comack et al., 2009; Totten, 2009). The need for a sense of belonging and access to life's basic necessities of food, clothing, a bed to sleep in, and social interaction are often an acceptable tradeoff for children who succumb to being sexually exploited. Intervention and exit strategies for sexually exploited Indigenous girls must consider these deep-rooted transgenerational impacts and culturally appropriate interventions.

Sociologist Patricia Hill Collins wrote about the overlapping forms of oppression that many women face in society (Collins, 2009). Multiple oppressive forces affect many young women, making them vulnerable to exploitation. Women involved in the sex industry also continually face judgments in society (Amahazion, 2014; Lozano, 2010; Doezema, 1998), often denied protection and security in their work and lives that others take for granted (Kempadoo \& Doezema, 1998). The five vulnerability factors most often mentioned in the Canadian Women's Foundation (2014) research were: (1) being female, (2) being poor, (3) having a history of violence or neglect, (4) a history of child sexual abuse, and (5) a low level of education.

Sociologists have coined the term intersectionality to explain multiple disadvantages and challenges that oppressed people face (Grace, 2014; Hankivsky, 2011; McCall, 2005). Grace (2014) highlights that intersectionality researchers "consider complex interactions between structures of 
power and oppression and interconnected aspects of individual and group identity and social location" (p. 1). Children and women in the sex industry face multiple compounded challenges, thus explaining the difficulty they have in escaping it.

An intersectional perspective is applicable to the issue of sexual exploitation. Ferguson (2005) wrote:

"In the intersections is where we fashion languages against coherence. Intersections are necessarily messy, chaotic, and heterodox. Why necessarily so? Because intersections are not about identity; they are about social dynamics" (p. 66).

The theory of intersectionality explains how and why people are vulnerable and exploited, both in the grooming and introduction to the sex industry and in the socialization, manipulation, power imbalances, and outright physical force that keeps them there. This creates a need to explore interventions and strategies around sexual exploitation while considering gender, economic disparity, and the social psychology of manipulation. The intervention and eradication of sexual exploitation requires a collective approach that considers a set of multi-faceted variables which contribute to the root of the issue. These variables include transgenerational traumas related to colonization, early childhood sexual abuse, poverty, and their related effect on lost educational and job opportunities for victims of sexual exploitation.

\section{CONCLUSION}

This research contributes to our understanding of poverty as a significant component in the industry of sex and human trafficking. While impoverishment does not clearly lead to involvement in the sex industry, we find that many sex industry survivors are/were more vulnerable due to being impoverished. Basic needs, such as having a secure place to live, often literally mean survival in Northern climates, such as in Winnipeg where cold winter conditions could badly injure or kill an improperly dressed person within minutes. Inadequate housing, or no housing at all, often compounded by extreme substance abuse and other intersectional challenges, results in women and girls falling back into the only outlet that is available for them to survive-performing sex acts for money.

The fundamental ideas of reducing poverty and providing opportunities for young people to have a different way of earning a living and having safe housing seems to be at the root of any solution to the problem. Poverty and the lack of affordable social housing affects people of all ethnic groups when they are challenged by it. Reduced disparity and poverty, and improved housing prospects, could improve resistance to victimization in the sex industry; therefore, governments, and the broad spectrum of service agencies, should focus on helping sex industry survivors.

Social service agencies could do more to identify children at risk, and educate them and their caregivers about the hazards of being targeted and groomed into the sex industry. This includes, in particular, youth from the North coming to larger urban centres to continue their education. We need to provide more safe refuge for women and girls involved in the sex industry. Manitoba does have shelters for victims of domestic violence, but insufficient shelters for women trying to escape the sex industry.

Existing systems and services need to be friendlier and accessible to survivors to "meet them where they are at" (Chrismas, 2017), rather than making them bend to the need of service providers. Examples of this are medical, government, and non-for-profit services that are open only during the day when they are needed at night. Systems and services also need to be more flexible in meeting survivor's needs; for example, not "aging out" victims the day they turn 18 , or telling a survivor to wait three weeks for entry into addictions programming.

Improved resilience to victimization seems to be key in supporting women and girls to avoid the sex industry and for survivors to escape it. This is done, in part, through poverty reduction and improved educational and employment opportunities. Chrismas (2017) found that a great deal of opportunity exists for creating better opportunities to people in Manitoba and Canada. The most effective interventions lie in prevention. Poverty reduction, including access to affordable housing, is an important goal that we can collectively work toward, and help survivors take back the power.

\section{ACKNOWLEDGMENTS}

The authors wish to acknowledge the survivors, and the people who work tirelessly in government and non-government organizations to empower and assist them.

\section{CONFLICT OF INTEREST DISCLOSURES}

The authors declare they have no conflicts of interest.

\section{AUTHOR AFFILIATIONS}

*Political Sciences Department, University of Winnipeg, Winnipeg, $\mathrm{MB} ;{ }^{\dagger}$ Arthur V. Mauro Center for Peace and Justice, University of Manitoba, Winnipeg, MB, Canada.

\section{REFERENCES}

Amahazion, F. (2014). Global anti-sex trafficking: State variance in implementation of protectionist policies. Human Rights Quarterly, 36, 176-209.

Burton, J. (1997). Violence explained: The sources of conflict, violence and crime and their prevention. Manchester, UK: Manchester University Press.

Canadian Women's Foundation. (2014). From heartbreaking to groundbreaking: Stories and strategies to end sex trafficking in Canada. Toronto, ON: Canadian Women's Foundation. Available from: https://www.canadianwomen.org/wp-content/uploads/2017/09/CWF-TraffickingReportDonor-EN-web.pdf

CBC. (2014, August 17). Tina Fontaine, 15, found in bag in Red River. CBC News.

CBC. (2008, May 16). Residential Schools: Aggressive assimilation. CBC News.

Charmaz, K. (2005). Grounded theory in the 21 $1^{\text {st }}$ century: Applications for advancing social justice studies. In N. K. Denzin \& Y. S. Lincoln (Eds.) The SAGE handbook of qualitative research, $3^{\text {rd }}$ ed. (pp. 507-35). Thousand Oaks, CA: Sage Publications.

Chrismas, R. (2017). Modern day slavery and the sex industry: Raising the voices of survivors and collaborators while confronting sex trafficking and exploitation in Manitoba, Canada [PhD thesis]. Winnipeg, MB: University of Manitoba. Available at: http://hdl.handle.net/1993/32586

Collins, P. H. (2009). Emerging intersections-Building knowledge and transforming institutions. In B. T. Hill and R. E. Zambrana (Eds.), Emerging intersections: Race, class, and gender in theory, policy, and practice. New Brunswick, NJ: Rutgers University Press. 
Comack, E., Dean, L., Morrisette, L., \& Silver, J. (2009). If you want to change violence in the 'hood, you have to change the 'hood: Violence and street gangs in Winnipeg's inner city. Winnipeg, MB: Canadian Center for Policy Alternatives.

Cullen-DuPont, K. (2009). Human trafficking (Global Issues), $1^{\text {st }}$ edition. New York, NY: Infobase Publishing.

Doezema, J. (1998). Forced to choose: Beyond the voluntary vs. forced prostitution dichotomy. In K. Kempadoo \& J. Doezema, (eds.), Global sex workers: Rights resistance, and redefinition (pp. 34-51). New York, NY: Routledge.

Farley, M. (2003). Prostitution, trafficking, and traumatic stress. Binghamton, NY: Haworth.

Ferguson, R. A. (2005). Racing homonormativity: Citizenship, sociology, and gay identity. In P. E. Johnson \& M. Henderson (Eds.), Black queer studies: A critical anthology (pp. 50-67). Durham, NC: Duke University Press.

Friesen, J. (2014, December 5). Winnipeg police told to stress protection of Indigenous women. The Globe and Mail.

Glowbal Act (2018). Human trafficking website. Available from: http://www. glowbalact.com/en/humantrafficking/

Grace, D. (2014). Intersectionality-informed mixed method research: A primer. Burnaby, BC: Simon Fraser University, The Institute for Intersectionality Research \& Policy.

Government of Manitoba. Department of Finance. (2018a). Supplementary Budget Paper F: Reducing poverty and promoting community involvement. Winnipeg, MB: the Author.

Government of Manitoba. (2018b). Manitoba Housing Website. Accessed May 3. Retrieved from https://www.gov.mb.ca/housing/about/about. html

Hallett, B., Thornton, N., \& Stewart, D. (2006). Aboriginal People in Manitoba. Winnipeg, MB: Manitoba Indigenous Affairs Secretariat.

Ham, J. (2014). Hope, healing, and the legacy of Helen Betty Osborne: a case study exploring cross-cultural peacebuilding in Northern Manitoba [Masters thesis]. Winnipeg, MB: University of Manitoba.

Hankivsky, O. (2011). Health inequities in Canada: Intersectional frameworks and practices. Vancouver, BC: University of British Columbia Press.

Kempadoo, K., \& Doezema, J. (eds.). (1998). Global sex workers: Rights resistance, and redefinition. New York, NY: Routledge.

Lozano, S. (2010). Theoretical reading on 'trafficking' in Women for the purpose of sexual exploitation in prostitution: Case of study: Colombia [Masters thesis]. Desafíos, Bogotá: Central European University.
Macleod, J. (1995). Ain't no makin' it: Aspirations and attainments in a lowincome neighborhood. Boulder, CO: Westview Press.

Mandel, C. (2016, March 8) Indigenous girls face tough hurdles, new report on women in Canada states. National Observer.

McCall, L. (2005). The Complexity of Intersectionality. Signs, 30, 1771-1800.

Nelles, W. (2006). Bosnian education for security and peacebuilding? International Peacekeeping 13, 229-241.

Nelson, J. (2014, May 20). Modern-day slavery generates billions: UN report. Globe and Mail.

Norris, M. J., Beavon, D., Guimond, E., \& Cooke, M. J. (2000). Migration and residential mobility of Canada's Aboriginal groups: An analysis of census data. Poster prepared for the Annual Meeting of the Population Association of America, Los Angeles. Ottawa, ON: Indian and Northern Affairs Canada.

Norris, M. J., Kerr, D., \& Nault, F. (1995). Projections of the population with Aboriginal identity, Canada, 1991-2016: Summary report. Population Projections Section, Demography Division, Statistics Canada, prepared for the Royal Commission on Aboriginal Peoples. Ottawa, ON: Canada Mortgage and Housing Corporation.

Partnership for Strong Communities (2012). Housing \& Educational Success: Closely Connected. Available from: http://www.pschousing.org/files/ PSC_PolicyBrief_Hsg\%26Education.pdf

Paper ney, A. M. (2009, August 27). Latest deaths of native women may be linked to crack-for-sex case. Globe and Mail.

Press, J. (2017, September 13). Census: Children make up one quarter of $4.8 \mathrm{M}$ Canadians living in poverty. CTV News.

Totten, M. (2009). Aboriginal youth and violent gang involvement in Canada: Quality prevention strategies. IPC Review, 3, 135-56.

UNODC. (2014). Global report on trafficking in persons 2014. Vienna, Austria: UN Office on Drugs \& Crime. Available from: https://www.unodc. org/res/cld/bibliography/global-report-on-trafficking-in-persons_html/ GLOTIP_2014_full_report.pdf

Volkan, V. D. (1997). Bloodlines: From ethnic pride to ethnic terrorism. New York, NY: Farrar, Strauss and Giroux.

Welch, M. A. (2014, January 24). New database lists 824 murdered, missing native women in Canada. Winnipeg Free Press.

Younging, G. (2009). Inherited history, international law, and the UN Declaration. In G. Younging, J. Dewar \& M. DeGagné, Response, responsibility and renewal: Canada's truth and reconciliation journey. Ottawa, ON: Aboriginal Healing Foundation. 